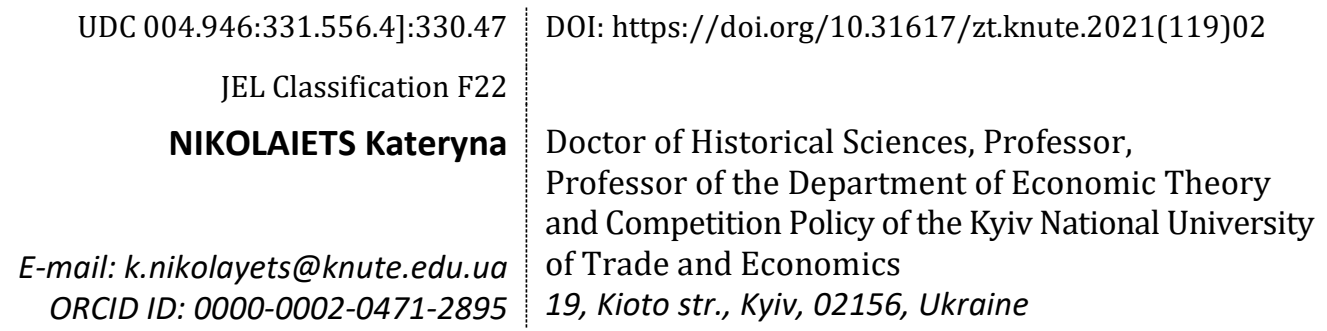

\title{
VIRTUAL LABOR MIGRATION
}

The concept of «virtual labour migration» and the main reasons for its emergence and spread in current conditions was defined. The consequences of the spread of remote work in analytical activities and the collection and structuring of information were outlined. The connection between the spread of «virtual labour migration» and the «brain drain» and the prospect of implementing innovative projects has been identified. The main threats to production organisation in the long-term use of remote work and involvement in «virtual labour migrants» tasks are highlighted.

Keywords: migration policy, population migration, population employment, external labour migrations, national security.

Background. In the classical sense, migration is the mechanical movement of people across the borders of certain areas with a change of residence or for a defined period. The specific circumstances are determined by the duration of work, study or tourist travel. The reasons for migration are wars, the need to find a more comfortable place to live, the desire for self-realization, a better paying job, quality education and more. But the unifying factor is the ability to get what you want solely in another place of residence or stay, which necessitated the mechanical movement of people. Recipient countries were selected based on information received, as a rule, from previous migrants who managed to satisfy their desires. Other sources of information were merchants, travellers, conquerors, pirates, smugglers, etc. Still, their information about the charms of other lands could not always be the basis for mass displacement of the working population. The most common reason for labour migration was the prospect of enrichment in a relatively short period (for example, "gold rush») or the prospect of free disposal of labour (mostly on their land or in production organized in a way impossible at the last place of residence). However, with the current level of development of information and communication technologies (ICT), remote mass work for a foreign customer with a free choice of residence has become possible.

Progress in the development of ICT has provided people with the opportunity to analyse, coordinate work and ensure interaction in a way that

(C) Nikolaiets K., 2021 
seemed impossible before [1]. Collecting, processing and transmitting information via computer networks connected to the Internet has made possible the so-called «virtual labour migration», where workers and employers can provide the desired results without physical movement between countries. Virtual labour migration can be considered the performance of tasks permitted by law at the request of employers whose businesses are registered in another place or country. At the same time, the employee remains at the previous residence. Typically, most of these tasks are performed using computer technology and involve active work on the Internet. The spread of the COVID-19 pandemic gave a significant impetus to the spread of «virtual labour migration», as between March 5 and 20, 2020, a large number of European countries suddenly restricted communication, movement across borders and tightened movement controls. As of November 2, 2020, 221 countries and territories have introduced 100065 restrictions on movement, the most common medical (64 460) and entry bans and restrictions on certain territories and countries (27 830). And extreme restrictions on movement were the first regulatory reaction of most governments [2, p. 11]. Large-scale traffic restrictions have led to increased use of computer networks for work and study. Remote work has become one of the most common work organizations in many consulting and investment firms. It has become mainly used to obtain the results of analytical work.

Analysis of recent research and publications. Some aspects of the chosen research topic are presented in the works of T. Baird [3], D. Zakh, M. Lucke [4], Ye. Kirichenko [5], E. Libanova [6], O. Malinovska [7] and others. Researchers have highlighted the circumstances of education migration. They showed the impact of information and communication technologies on this process. Researchers analyze the impact of the mental environment on labor migration. E. Libanova studied external labor migration from Ukraine to Europe and its significance for economic development. O. Malinovska identified the reasons for the refusal of migrants to return to Ukraine. However, most researchers prefer to study labor migration. They don't assess the consequences of involving employees in virtual migration.

The aim of the study is to determine the main factors influencing the «virtual labour migration» and prospects for its development in terms of accelerating the progress of information and communication technologies.

Materials and methods. The paper uses data from individual companies related to data exchange protection on the Internet. SWOT analysis, critical discourse analysis, hierarchy analysis method and culturological method of scientific research were used to ensure the appropriate level of verification of conclusions.

Results. The development of modern information and communication technologies and the universalization of the language of business 
communication in the world have created the preconditions for the spread of «virtual labour migration», which has become the primary means of income for some workers. The development of «virtual labour migration» received a significant impetus in the context of the COVID-19 pandemic, when a substantial number of workers were forced to work remotely. The provision of distance education services has also become widespread. And if such measures were primarily considered unproductive at first, it became clear that the organization of remote work has certain advantages over time. Such advantages have been a sharp reduction in employers' costs of maintaining or renting office space, ensuring the relocation of workers to perform certain types of work, the ability to dramatically speed up the exchange of information between employers and employees, and so on. However, there were also significant obstacles to the organization and operation of business structures. These include difficulties in monitoring the activities of employees, the need for additional costs for technical support of remote work, the fundamental impossibility of its organization for specific categories of employees (including in the field of education), as well as difficulties in finding and ensuring confidential business contacts, protecting information transmitted electronically and the logistics of transferring the necessary data.

In such conditions, the most common is the performance of remote analytical work and information retrieval tasks. It was important for employers that employees in less developed countries could perform some analytical work. Therefore, although modern ICTs can benefit the economic integration of migrants and, consequently, contribute to the host country's economic growth, such technologies can potentially deter migrants from living in a country with a relatively higher standard of living [8].

In this case, the opportunity to be in a familiar environment while retaining the option to communicate with family and friends remains attractive for «virtual migrants». For some of these «migrants», there is no need to look for housing and premises for office work, as in many cases, they have the technical ability to organize work at home. Workers also do not need to adapt to climate change in their new workplace. And a familiar environment helps reduce stress and increase opportunities for balanced evaluation of available information. A negative factor for employers may be reducing the level of scientific abstraction and, accordingly, narrowing the conclusions proposed in the organization of analytical work in underdeveloped countries. The lack of an appropriate business or scientific environment for communication plays a negative role. Providing such communication in an online format requires additional efforts. Due to a particular formal setting, which may not facilitate the exchange of views between professionals, they could resort to a more relaxed environment. Most analysts who work remotely are aware that their communication over 
the Internet can be recorded. Therefore, such communication can hinder the definition of copyright and requires a specific organization to ensure a free exchange of views between professionals.

The placement of a significant amount of data on the Internet causes an increase in interest in access to modern information and communication technologies, including communication platforms and platforms where users share the necessary information. However, an essential component of the information exchange organisation is to ensure the possibility of confidential communication. At the same time, the involvement of artificial intelligence in the creation and exchange of information will gradually cause even more tension in the organization of online communication between employees. Therefore, the format of online meetings with the obligatory inclusion of video communication will be the most probable. This will require an increase in the speed of information transfer and appropriate opportunities to store large databases.

«Virtual labour migration» can be organized in the format of foresight for the involvement of employees of various institutions and organizations with the gradual identification of the most knowledgeable professionals. It is also possible that at certain stages of processing the available information, the method of «brainstorming» will continue to be used when the exchange of views takes place through online conferences.

The large-scale involvement of analysts from other countries will inevitably pose a challenge to governments to protect national interests. Conclusions are drawnthat»virtual migrant workers» may have actual or potentially dangerous consequences for the country in which they live and provide competitive or other benefits to those interested parties.

It is especially noticeable in the IT market when some countries, including Ukraine, create favourable conditions for the involvement of relevant professionals. On the one hand, their product can be used to develop the national economy. Still, on the other hand, the results of their work can potentially be used more effectively to organize or modernize production abroad, especially if the customer was a foreign firm or organization. In addition, monitoring the workload and the nature of such work can simplify the performance of forecasting functions associated with creating futurological forecasts for the development of certain enterprises or industries. For example, the efforts of China, the United States and the Russian Federation to monitor via mobile devices and social networks are well known.

A negative consequence for some countries may be a significant advantage of the economic implications of introducing the achievements of «virtual migrant workers» by foreign producers over the economic effect of investing the salaries received by such «migrants» in the national economy. This effect is objectively determined, as employers 
expect profits that should significantly exceed the cost of paying the money earned by «virtual migrant workers».

In fact, «virtual labour migration» can be the latest way to «brain drain» and is all the more threatening because most countries that hire migrants do not spend money on their training. Such training usually takes place to the extent that employers are interested in it. This makes it promising to form modern, influentialhubs with analysts from various countries who will work on individual problem parts, often not realizing (or not having the information for such awareness) the scale of the problem as a whole.

However, increasing the capacity of developing countries to increase the availability of high-quality, timely and reliable data graded by income, gender, age, race, ethnicity, migration status, geographical location, and other relevant characteristics in the national context can contribute to their sustainable development [9].

«Virtual migrant workers» who receive regular assignments from certain countries are gradually becoming more interested in sustainable development. Such interest can have different consequences. On the one hand, it can provide the necessary efforts for introducing innovative technologies. Still, on the other hand, it will help increase the level of foreign interference in the affairs of other countries. Such interference can pose a potential threat to national interests, as «external migrant workers» can extrapolate their values and worldviews to solve problems outside their own country.

In some cases, the nature of understanding such problems and the idea of possible ways to solve them may conflict with those acceptable to the local population. In addition, the very fact of the intervention of foreigners who are not citizens of a particular country, but only perform the tasks of enterprises or organizations located in its territory, may be negatively perceived by society. At the same time, the artificial separation of «virtual migrant workers» from the problems of the employer country can harm both the quality of work and participation in its organization. Executors will have no incentive to assess the issue in a broad sense, will focus on a specific task, deviating from the awareness of the general consequences of the work.

ICTs remain an essential factor in attracting migrants to sociopolitical processes. The inability to adequately socialize on this issue provokes marginalization, as migrants do not have full access to crucial decisions [8]. The consequence, as a rule, is «social alienation». Its manifestation is the so-called «man of the world», who does not feel attached to the Motherland, but puts consumer interests first, choosing a place of work solely guided by selfish motives. This, in turn, complicates the rational use of the potential of «virtual migrant workers», including through the artificial «shredding» of the scale of 
work (to prevent their service) and creates problems in the field of logistics and coordination of their efforts.

An increase in the level of stress due to the specifics of the organization of their work can also be a problem for «virtual labour migrants». Without moving outside their home for long periods and working on a computer, they «virtualize» their world and environment perceptions. By narrowing the circle of their communication, focusing mainly on analytics, and finding the information necessary for the customer, they react negatively to domestic problems and difficulties arising in the work process. And often, such difficulties are perceived as a sign of their own inability to cope with the work. Therefore, corporate communication is necessary for employers to ensure a high level of «virtual migrant workers» work. And in some cases, such an organization leads to the rejection of remote work with the seasonal use of this format of work or its use in periods when it is necessary to process a large amount of information, or it is essential to obtain certain conclusions or forecasts quickly.

At the same time, «virtual labour migration» allows increasing data management in cyberspace [10]. This increase is possible due to the interest of employees in the authorization of their achievements, data protection and a high level of competition between employees engaged in analytical work. Even a simple SWOT analysis allows you to identify possible risks of loss or damage to information and form warnings about potential unauthorized access to it. Accordingly, employees interested in the work results will primarily be responsible for the preservation of data sets. But ensuring such an interest for employers will gradually become an increasing problem, including the potential for establishing horizontal links between the participants in various projects.

The potential of cyberspace provides a previously unattainable level of human communication and forms an interconnected world in which action is not and cannot be limited by physical boundaries. Such a world does not fall under traditional rules, hierarchies or power relations [1]. Significant complexity, and in some cases the fundamental impossibility of exercising power, even within individual enterprises, whose work is implemented in cyberspace, will require a substantial revision of labour legislation. And it's not just about the needs caused by the need to pay taxes, fees or the formation of pension funds. It will also be essential to ensure that the labour legislation of some countries is adapted to the bill of others, as «virtual migrant workers» can use the gaps in it for their purposes. In addition, the possibility for the participants of a particular project to take action to the detriment of its organizers is also dangerous if it is impossible to bring employees to justice in another country. This, in turn, can serve as an incentive to involve the diasporas of certain countries in the search for contractors or clients and control over individual workers. 
Control over «virtual workers» will require significantly greater efforts in developing security and surveillance technologies [3]. Ensuring such control and monitoring will be an essential component of transaction costs for employers. The topical question remains which security and privacy policies and technologies will be adequate to address the current critical security and privacy issues of large databases [11], and to what extent «virtual migrant workers» will be willing to share their work and participate in new projects aimed at modernizing previously obtained results. The digitalization of analogue databases and the involvement of «virtual migrant workers» in this process will also remain a problem. These are, for example, state archives, in which documents for better storage will be digitized and increase the total amount of documentation prepared exclusively in digital form. Accessing «virtual» analysts to this type of database can be a severe problem for state and commercial secrecy. The fact is that «virtual migrant workers» who can be tasked with finding and processing relevant information do not have to be aware of the civil rights and responsibilities of the country where the relevant data is posted. This, in turn, will serve to discard restrictions on the nature and uses of the information. An example is disclosing information on procurement violations of international sanctions, cases of agreements in breach of competition rules and antitrust law.

The spread of ICT contributes to the digitalization of information about new vacancies. This exacerbates competition between employees, as it simplifies access to relevant information. The development of ICT affects employment as an industry and as a tool. New employment opportunities using ICT are essential because most countries seek to create promising jobs to ensure positive economic and social consequences for workers and society [12]. At the same time, the worldviews of «virtual labour migrants» are being formed. And the basis for them must be universal values.

Therefore, government agencies and organizations and private companies' management should form corporate ethics and responsibility. This aspect is critical because representatives of different religions, moral principles and ideological beliefs can work in cyberspace on one project. The spread of the "shadow economy» and the involvement of the underworld in working in a virtual environment should not be overlooked. Open requests or competitions for a specific job can attract different people. And they don't have to have similar views on the prospects of participating in particularpositions. At the same time, some companies, given that employees who work remotely do not spend money on transport, announced a reduction in their salaries. Thus, in August 2021, Google announced similar intentions. However, employees opposed the decision, saying they were ready to return to office work if needed. Similar attempts have been recorded in several European companies. But in general, the revision of wages has not yet reached an impressive scale. With the abolition of quarantine restrictions, many 
workers would prefer to return to work as usual. On the other hand, large companies that can finance global or regional projects are interested in the prevalence of "virtual labour migration» in countries with low tax rates for IT professionals.

Conclusion. Large-scale «virtual labour migration» turned out to be a forced phenomenon. However, the emergence and expansion of technical capabilities that allow organizing such work suggest the prospects for remote analytical work and the collection and structuring of specific data. For such work, work in offices can be replaced by remote. However, as the experience of 2020-2021 has shown, a significant number of office workers do not see the best way to organize labour remotely. And the point here is not only in the possible limitation of earnings but also in the loss of the atmosphere that allowed to produce the most balanced and timely decisions.

At the same time, the spread of «virtual labour migration» creates several problems in the field of national security and trade secrets, which can be associated with the imperfection of technical means of storing and transmitting information, and the so-called «human factor». The lack of interest of several specialists involved in the remote performance of tasks in the firm's fate may hurt the organization of the production process. At the same time, the long-term work of «virtual labour migrants» on foreign customers creates a basis that can negatively affect the civic identity of employees. The most vulnerable category is IT specialists, who are most involved in projects funded from outside the country. Remote work and the spread of cyberspace also require a review of the legislation of several countries, at least in the context of ensuring the copyright of «remote migrant workers» in their development and achievements.

\section{REFERENCES}

1. Martin, William J. (1998). The Information Society (Aslib Press, London) [in English].

2. Kul'chyc'ka, K., Kravchuk, P., \& Sushko, I. (2020). Transformacija trudovoi' migracii' z Ukrai'ny do JeS pid chas pandemii' COVID-19 [Transformation of labor migration from Ukraine to the EU during the COVID-19 pandemic]. Kyi'v: Friedrich Ebert Stiftung [in Ukrainian].

3. Baird, Theodore (2017). Interest groups and strategic constructivism: business actors and border security policies in the European Union. Journal of Ethnic and Migration Studies, (pp. 1-19) [in English].

4. Zah, D., \& Ljukke, M. (2020). Zagal'ne zrostannja trudovoi' migracii' [Overall growth of labor migration]. Retrieved from https://www.epravda.com.ua/rus/ publications/2020/02/11/656895 [in Ukrainian].

5. Kyrychenko, Je. (2020). Povernuty trudovyh migrantiv dodomu: chy potribno ce robyty zaraz [Bringing migrant workers home: should it be done now?]. 
Retrieved from https://www.epravda.com.ua/publications/2019/10/8/652359 [in Ukrainian].

6. Libanova, E. M. Trudova migracija z Ukrai'ny: vplyv COVID-19 [Labor migration from Ukraine: the impact of COVID-19]. Retrieved from http://www.nas.gov.ua/UA/Messages/Pages/View.aspx?MessageID=6547 [in Ukrainian].

7. Malynovs'ka, O. A. (2018). Migracijna polityka: global'nyj kontekst ta ukrai'ns'ki realii' [ Migration policy: global context and Ukrainian realities]. Kyi'v: NISD [in Ukrainian].

8. Peter, Parycek, Margarita, Fourer, Shefali, Virkar, Dino, Pitoski, Gabriela, Viale Pereira, Thomas, \& J. Lampoltshammer. Impact of Information and Communication Technologies and their Application to Challenges of Migration. Retrieved from https://www.researchgate.net/publication/321677958_Impact_ of_Information_and_Communication_Technologies_and_their_Application_to_ Challenges_of_Migration [in English].

9. Laczko, Frank (2015). Improving Data on International Migration and Development: Towards a Global Action Plan?. Discussion Paper (IOM Global Migration Data Analysis Centre). Retrieved from https:/gmdac.iom.int/ sites/default/files/papers/Improving\%20Data\%20on\%20International\%20 Migration\%20and\%20Development-\%20Towards\%20a\%20Global\%20Action\% 20Plan\%3F.pdf [in English].

10. Lehtonen, P., \& Aalto, P. (2017). Smart and secure borders through automated border control systems in the EU? The views of political stakeholders in the Member States. Retrieved from https://www.tandfonline.com/ doi/full/10.1080/09662839.2016.1276057 [in English].

11. Moura, J., \& Serrao, C. (2015). Handbook of research on trends and future directions in big data and web intelligence. Retrieved from https://www.researchgate.net/publication/281404634_Security_and_Privacy_ Issues_of_Big_Data [in English].

12. Zaman, Noor, Elhassan, Seliaman Mohamed, Fadzil, Hassan Mohd, \& Fausto, Pedro Garcia Marquez. (2013). The World Bank. How information and communication technologies could help expand employment opportunities. Retrieved from http://documents.worldbank.org/curated/en/290301468 340843514/ pdf/809770WP0Conne00Box379814B00PUBLIC0.pdf [in English].

The article submitted to editor's office on 27.08.2021.

\section{Ніколаєць К. Віртуальна трудова міграція.}

Постановка проблеми. «Віртуальною трудовою міграцією» можна вважати виконання прачівниками дозволених законодавством завдань на замовлення роботодавців, чий бізнес зареєстрований в іншому місиі або країні, залишаючись на попередньому місиі проживання.

Метою дослідження є визначення основних факторів, що впливають на «віртуальну трудову міграцію» та перспектив ї розвитку в умовах прискорення прогресу інформаџійно-комунікаційних технологій.

Матеріали та методи. У статті використано матеріали соиіологічних досліджень, що пов'язані з організацією захисту обміну даними в мережі Internet. Для забезпечення належного рівня верифікації висновків 
застосовано методи: SWOT-аналіз, критичний дискурс-аналіз, аналізу ієрархій і культурологічний наукового пошуку.

Результати дослідження. Розвиток сучасних інформаційнокомунікаційних технологій та універсалізація використання мови ділового спілкування у світі дали змогу сформувати передумови для поширення «віртуальної трудової міграчїі», яка для частини прачівників стала основним засобом отримання прибутків. Розвиток «віртуальної трудової міграцї̈» отримав суттєвий поштовх під час пандемії COVID-19. Найбільшого поширення набуло виконання дистаниійної аналітичної роботи та завдань з пошуку інформачії. "Віртуальна трудова міграція» може бути організована у форматі форсайту за залучення до виконання завдань працівників різних установ та організацій з поетапним визначенням найобізнаніших з иією проблемою фахівиів. Проте зовнішні трудові мігранти можуть екстраполювати власні иінності та світоглядні орієнтири на розв'язання проблем поза межами власної держави.

Висновки. Масштабна «віртуальна трудова міграчія» виявилася вимушеним явищем. Однак завдяки появі та розширенню технічних можливостей, що дають змогу на належному рівні організувати подібну роботу, можна стверджувати про перспективність віддаленої аналітичноі роботи та збирання і структуризачії певних даних. Водночас поширення «віртуальної трудової міграції» створює низку проблем у сфері національної безпеки та збереження комериійної таємниці, які можуть бути пов'язані як із недосконалістю технічних засобів збереження та передачі інформачії, так $i$ з так званим «людським фактором». Відсутність зачікавленості деяких спеціалістів, залучених до дистаниійного виконання завдань, у долі фірми може негативно відбитися на організації виробничого прочесу. Тривала робота «віртуальних трудових мігрантів» на закордонних замовників створює підгрунтя, яке може негативно позначитися на громадянській ідентичності працівників. Дистанційна робота та поширення кіберпростору також вимагають перегляду законодавства низки краӥн, принаймні у контексті забезпечення авторських прав «віддалених трудових мігрантів» на їхні розробки та здобутки.

Ключові слова: міграційна політика, міграції населення, зайнятість населення, зовнішні трудові міграції, національна безпека. 